\title{
4 \\ Creating Chronic Food Insecurity in the Gold Coast Colony
}

In the nineteenth century, considerable turbulence was unleashed along the vast trade networks that had for so many centuries defined social and economic interactions from the West African coast to the Sahara. This turbulence resulted from a complex array of sources. The Atlantic slave trade was formally brought to a close, cutting off many polities from a prime source of income. At the same time, economic recession, political maneuvering, and ideological shifts across the globe led European governments to scramble for African land and resources after the trade in African people was outlawed. The friction among these desires contributed to local hostilities, resulting in violence and dislocation over wide swathes of regions encompassed by the modern nation-state of Ghana and beyond. By the end of the nineteenth century, the imposition of colonial boundaries had quelled much of this upheaval, but for many areas did little to make up for the losses already suffered. Colonial governments ushered in a new era, one in which the value of commodities was defined in European capitals, which in turn etched "development" unevenly across African landscapes and social groups.

The impacts of these economic and political shifts in the late nineteenth through mid-twentieth centuries varied across the landscape. In some areas, these changes provided the necessary preconditions for the entrenchment of chronic food insecurity. Demographic collapse and the imposition of marketbased economic policies fixed the seasonal food shortage known as the hungry season gap into a permanent feature of some African livelihoods. Yet these forces remained largely invisible to British officials, who tended to suffer from historical amnesia and often viewed Africans as lazy and backwards. In this chapter, I follow in the footsteps of numerous scholars who have demonstrated the invalidity of these timeless stereotypes. Instead, I investigate how Africans coped with the loss of human capital-both people and the knowledges and labor they provided-and remade their lives in the uncertain conditions that prevailed in 
the colonial period. Returning again to Banda, I show how early colonial (189os-1920s) policies indirectly impacted peoples' ability to feed themselves, and the ways that farmers and cooks maneuvered their limited resources to make ends meet. I also visit the Tallensi, situated to the far north of Banda, to survey how later colonial (1930s-1940s) attempts to understand African peoples and nutrition scientifically did little to ameliorate experiences of hunger.

\section{COLONIALISM AND FOOD SECURITY}

In the historiography of Africa, the impact of colonialism on African health and well-being has been a long-standing if unresolved research question (Lappé and Collins 1978; Worboys 1988). Colonial economic policies, particularly the focus on cash-cropping and market economies, fundamentally altered peoples' relationships with the land and its products (Giblin 1992; Doyle 2006; Iliffe 1987; Mandala 2005; Moore and Vaughan 1994; Watts 2013). Whether those impacts were negative or positive has long been debated. Earlier scholars tended to assume "that in pre-colonial times hunger, even famine, was more prevalent than today, despite the dramatic droughts of the Sahel region and the rapid growth of population in recent times" (Goody 1982, 58). The idea that American crops made up for losses suffered to slavery (chapter 4 ) relies on a similar set of presumptions: that Africans were worse off in precolonial times, and that European interventions increased food security. Assumptions like these were rarely evaluated by means of evidence, but instead appear to be the product of the ideologies common at the time, as well as of the use of a baseline precolonial Africa derived from early colonial referents. In this section, I train attention on how the impact of colonialism is assessed, specifically focusing on how scholars have dealt with the so-called precolonial period.

One of the main challenges to evaluating the impact of colonial interventions is the limited information-or perception thereof-that we have about precolonial food security (Doyle 2006, 1; Shaffer 2017). As I suggest in chapter 2, this is not necessarily due to a limitation of the archive per se, but rather a lack of dedicated focus to evaluating precolonial food security. People not specialized in early African history and archaeology often fall back on a imagined baseline precolonial period for comparative purposes, much as scholars like Goody and many that came before and after did. ${ }^{1}$ Audrey Richards, for example, used the start of her ethnographic mission in the early 1930 as her referent for "traditional" Bemba, glossing over the significant changes of the preceding decades (Moore and Vaughan 1994). In the last several decades, contemporary scholars have often used a late nineteenth-century referent, a time after the ravages of the trans-Atlantic slave trade and the troubled decades of violence in the mid- to late nineteenth century. This point is chosen not because it is most representative of precolonial history, but because the documentary record expands considerably in this period, 
making it more visible and accessible, particularly to the nonspecialist. However, as we have learned in the previous chapter and will continue to detail below, these decades represent a low point in historical food security in West Africa.

A case from northern Ghana illustrates some of the problems with this kind of approach. Shaffer (2017) pulls together information from an impressive array of disciplines, including linguistics, history, and ethnography, to evaluate whether colonial policies had a negative or positive impact on local food security in northern Ghana. He argues that hunger characterized the precolonial period, based on the existence of words for "hunger" in local languages recorded by Europeans in 1899 and 1906-observations made on the heels of extremely severe disruptions, detailed below-as well as references to hunger recorded in twentieth and twenty-first century greetings and proverbs. As Stephens (2018b, 791) has outlined, it is tremendously difficult to date proverbs, so Shaffer's use of proverbs to imply precolonial food insecurity needs to be interpreted with extreme caution. The precolonial period is also collapsed into what two Europeans could record on their brief visits in 1899 and 1906-which actually falls within the colonial period, and is certainly not representative of food security in the vast "precolonial" period. Although Shaffer (2017) acknowledges that these are weak sources, he nevertheless argues that the hunger season existed before colonial rule, despite not identifying a single source that alludes to this specific type of seasonal food insecurity. ${ }^{2}$

But whether or not hunger existed before colonial rule should not be our focal point: of course hunger occurred periodically, as Watts (2013) details for northeastern Nigeria and James LaFleur records in coastal Ghana (La Fleur 2012, 137-44), as it did elsewhere in the world. Banda's story suggests, however, that there was a much higher degree of resilience to drought and other sociopolitical troubles in precolonial times than has previously been understood. This case study prompts a different but related question, about whether the form and severity of hunger changed during the colonial period and thereafter. John Iliffe's (1987) meticulous study of the African poor across the continent argues that famine in particular decreased during the colonial period, but that low-level, more chronic poverty (and presumably, food insecurity) increased during this time. Famines are severe, rare events which often lead to considerable deaths from starvation and disease, and because of their severity tend to be remembered across oral and written archives. Often portrayed as resulting from severe environmental changes like drought, famines more typically result from a failure to distribute food supplies to those who need them most (Sen 1981). Iliffe claimed that colonial governments improved food distribution networks through the introduction of modern transportation, a technological development which has been credited with famine reduction all over the world. Note, however, that the technological capability to distribute food does not mean there is always the political will to do so (e.g., Davis 2001). Even with this technological ability, famine continues to reoccur in African contexts. While this tendency has been explained in multiple ways 
(i.e., entitlement failure, Sen 1981), part of the answer lies in the pervasiveness of chronic, seasonal hunger. Low-level shortages act to make people more vulnerable to major perturbations like famine (Watts 2013). While famines are often recorded in oral and written archives, chronic food shortage is less visible, making it a kind of "silent violence" (Watts 2013). The other difficulty in evaluating Iliffe's thesis is that he does not clarify the precolonial baseline he uses to evaluate the impact of colonial policies. Including this level of detail is a major challenge in any kind of comparative, synthetic history; when it is not included, the resulting suppositions tend to get repeated in subsequent literature all the same. One of Iliffe's most salient points was that colonialism's impact was not the same everywhere: in some regions, colonial policies deepened existing inequalities while in others these policies created new disparities. This observation underscores the need for regional case studies on food security during the colonial transition.

Scholars focusing on local case studies are more familiar with the diversity of archives, and consequently have tended to argue that food security declined as a result of colonial economic policies and their social impacts. In Malawi and Nigeria, Mandala (2005) and Watts (2013) suggest that precolonial African polities adhered to the tenets of a moral economy that insured the populace was well fed or at least better fed than in recent decades, and that this "subsistence ethic" was eroded under the transition to market economies. Although we must be cautious in recreating a "Merrie Africa" imaginary (Hopkins 1973, 10) in place of the scarcity slot, it is important to highlight that social strategies like labor organization and food redistribution are among Africa's chief developments in agriculture (Guyer 1984; Stone, Netting, and Stone 1990). Although noticed long ago by anthropologists, these innovations tend to go unacknowledged in other contexts because they are less visible than the technological innovations that define improvements to Western agricultural practice (Berry 1993; Guyer 1984; Stone, Netting, and Stone 1990).

Beginning with the pioneering work of Audrey Richards ([1932] 1964, 151-57), Africanists have highlighted the important role that chiefs played in insuring that their constituents were fed. The ability of a chief to feed his people helped him gain both followers and status. Provisioning would have thus been an important strategy in societies where the accumulation of people and their skill sets was valued (Guyer and Belinga 1995). Other social strategies also exist for leveling out uneven food supplies, such as food sharing between households and family members (Mandala 2005). Social relations and the expectation of food redistribution can be thought of as a critical entitlement (Sen 1981) that insured food security in some places. However, we cannot assume that these instances, drawn from specific nineteenth- and twentieth-century African societies, characterized all ancient African societies; to do so is to collapse regional variation and time and change in much the same way as the "baseline" approaches critiqued above. What they provide is an alternative example of how food security is maintained through social contracts. While Shaffer (2017) claims that changes to the moral economy are 
unrelated to colonial intervention, authors like Watts (2013) and Mandala (2005) point to the indirect but devastating impact of cash-cropping, wage labor, and individual accumulation, which together fundamentally challenged the logic of communal approaches. In the cases they consider, the destruction of these social relations and reordering of the relations of production undermined the ability of the least advantaged people to cope with environmental change (Watts 2013; see also Davis 2001).

Colonial policies were rooted in ideologies that discouraged many officials from seeing the benefits of African social strategies. These ideologies are numerous and often contradictory (Berry 1993) but worth briefly reviewing not only because they dictated approaches to agriculture in their new African colonies, but also because they infused the minds of many of the chroniclers upon whom we rely for information. The colonial mission was predicated on the idea that the African continent was rich in resources to be mined, rather than the epitome of scarcity it occupies in Western minds today. In the early colonial period and before, many British officials operated under the myth of exuberance-that tropical environments were rich and fertile, but that Africans were too lazy to exploit them appropriately (Curtin 1964). Such ideas helped motivate the colonial enterprise; the resources of Africa were ripe for the taking, if Westerners were willing to provide-or coerce-the labor needed to mine them. This stereotype thrived on historical amnesia; many African farmers suffered from a dearth of labor, following centuries of ruinous slaving, which Rodney (1972) argued limited their productivity (see also Carney and Rosomoff 2009). Indeed this productivity gap remains the focus of economists and development practitioners even today, often with very little acknowledgment of the historical reasons that it exists. Increasing the productivity of African farmers became part of the civilizing mission, but only if those farmers focused on cash crops.

At the same time, "there was a romanticization of pre-European African society which included ideas of moral innocence, a respect for African bush-skills, and a generalized notion of the noble savage" (Neumann 1995, 151). With preconceived notions like these, it is no wonder that most early colonial officials concerned themselves little with subsistence; it was generally assumed that Africans could feed themselves (Robins 2018). This negligence may have allowed most Africans freedom to cultivate what made sense to them, particularly in areas like Banda that lay outside of the main cash-cropping zones. This no-policy policy may also have meant that food insecurity flew under the radar for colonial officials, especially in the case of the low-level and chronic food shortages that Watts (2013) aptly termed "silent violence." Only later, once nutrition science made malnutrition visible beginning in the 1930s, did colonial officials realize the devastating impacts of ignoring subsistence agriculture, a subject I return to below.

These colonial ideologies were different in some ways from the scarcity slot mentality described in the introduction, but they show some ancestral similarities. 
They were based on an idea of Africa as a land of plenty rather than scarcity. Attitudes about the capabilities of Africans were conflicting: they were viewed on one hand as noble savages with skills to exploit their environments, and on the other, as lazy people unwilling to shoulder the burden of productivity. Each of these ideas was rooted in ahistorical space, with little acknowledgement of history or change, a practice also central to the modern reasoning of the scarcity slot.

In the first portion of this chapter, I show how the labor dynamics of the late nineteenth and early twentieth centuries were a major departure from earlier periods, and were misread by colonial officials as evidence of unproductivity. I focus on the early colonial period to 1930 in the British Gold Coast, a time frame for which we have complementary information from Banda that allows us to assess the impact of colonial rule there. In the last portion of this chapter, I consider the later colonial period (1930-57), when the new sciences of nutrition and anthropology allowed colonial officers to see and at times to ignore the extent of the hunger problem that their own policies may have caused.

\section{SURVIVING THE TURBULENT TIDES \\ OF EMPIRE BUILDING}

Early British interests in Africa were defined by commerce rather than by a desire to rule. But by the mid-nineteenth century, British concepts of race had changed, and a push towards dominance ensued, following similar developments in other European countries at the time (Bassil 2011; Lorimer 1978). In 1868, Britain and the Netherlands swapped some of their holdings to consolidate their respective territories along the Gold Coast. In the same time frame, the Asante state tried to establish formal control over several coastal polities with whom relations had long been contentious, and also began to invade territories protected by the British. The British responded by sacking Kumasi in 1874 and again in 1896. With the loss of her southern provinces and access to Atlantic trade, the Asante state was considerably weakened. Although the independent Asante state persisted for two more decades, several of its internal provinces and other factions revolted. By 1901, Asante (now known as Ashanti) was annexed to the Gold Coast colony, and the Northern Territories were annexed as a protectorate in 1902 (map 5; Gocking 2005, 37-47). The British were not alone in their conquest of African lands and peoples. European countries vied for land and power over much of Africa in the nineteenth century, resulting in formal claims to colonies at the 1884 Berlin Conference, where not a single African was present (Forster, Mommsen, and Robinson 1988).

The Gold Coast interior was of particular interest, for it lay at the intersection of competing British, French, and German claims. In 1892-94, the British dispatched George Ekem Ferguson to the far north to obtain treaties of friendship with the polities there (Arhin 1974, ix-x). Ferguson, born of Scottish and Fanti parents, was a civil servant trained in London in geology who had traveled widely throughout 


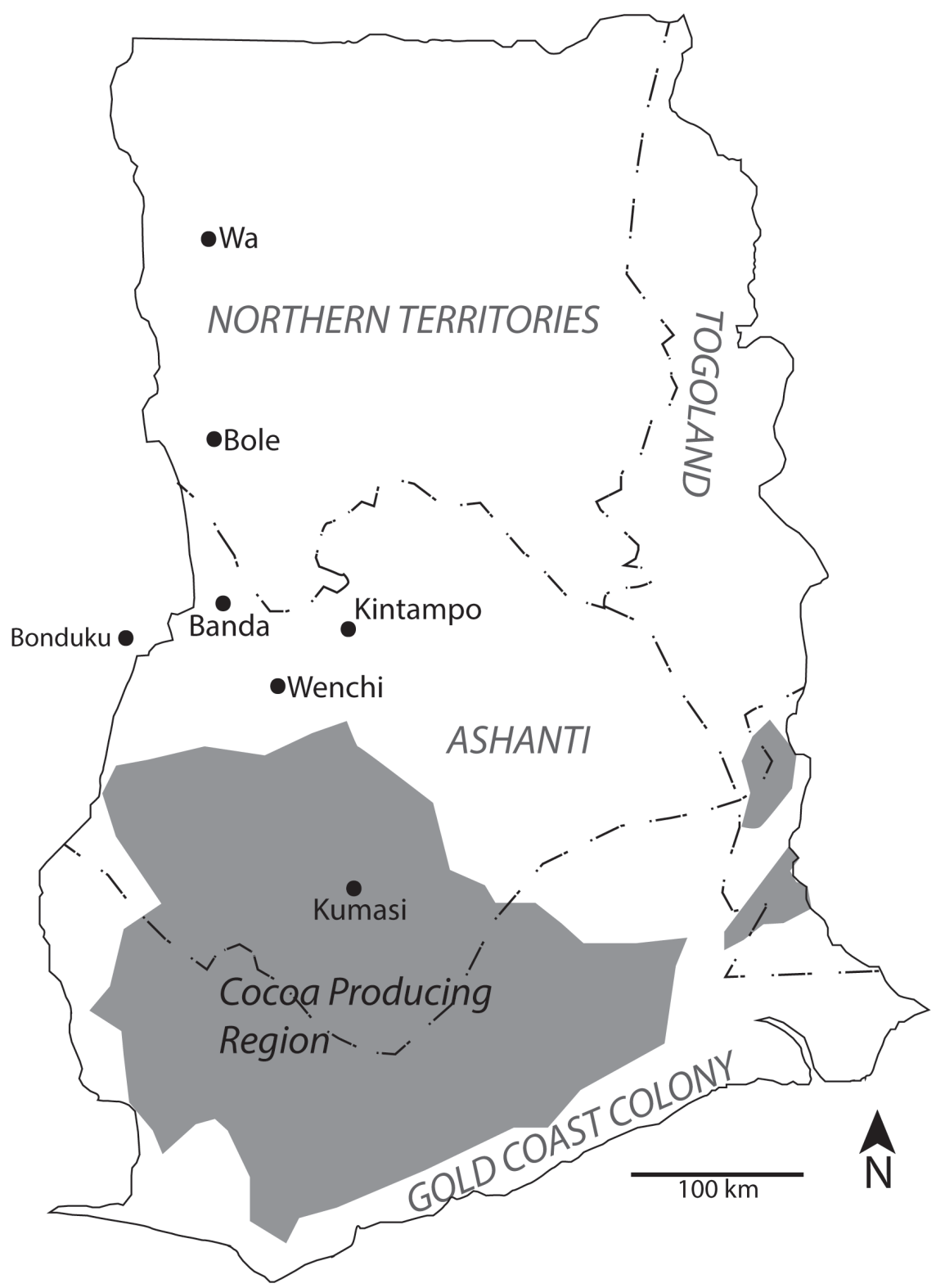

MAP 5. Divisions within the British Gold Coast, showing cocoa-producing regions, circa 1930. Note that the boundaries and names of regions have changed over time.

the Gold Coast in the service of various governors and later became a surveyor. However in the early and undeveloped colonial administration, Ferguson was employed as a jack-of-all-trades, particularly in settings that were considered 
dangerous for a European (Thomas 1972, 181-83). Ferguson apparently arrived on the heels of conflict in the Banda area, noting the "ruined villages of Banda" (Arhin 1974, 101, 113). The rulers of Banda signed a treaty with Ferguson in 1894, two years before Asante formally ceded to British control (Stahl 2001, 95-96). However, these initial British treaties were commercial in nature, and offered no guarantees of British protection (Arhin 1974, 66). This changed as British trade interests became threatened by the movement of Imam Samori and his Sofa army into the area (Stahl 2001, 96-97).

Samori and his forces waged wars of conquest between 1861 and 1898, and established a loose empire that stretched from Guinea to northern Côte d'Ivoire. By 1895 , he had settled his base of operations in Bonduku, the center of Gyaman, some eighty kilometers west of Banda, and began expanding east and northwards into what is today Ghana (Person 1968). Samori succeeded in establishing a line of posts across the Asante hinterland including in Banda, Bole, and areas northwards. His armies brought great unrest, raiding the surrounding areas for food and captives and scorching much of what was left, causing widespread food shortage and dislocation (see below; Stahl 2001, 96-98). The greatest impact was felt north of the Black Volta River (see Fell's 1913 report in ARG 1/2/21/3; Stahl and Cruz 1998).

In January 1896 the British received word that Samori had occupied Banda; further investigation by a Gold Coast constabulary suggested that Samori had taken 112 captives, as well as foodstuffs, from Banda. Henderson suggested that five hundred troops were needed to retake Bole from Samori, though concern was expressed over how to supply so many men with food since "there is practically none between Lawra [Bui] and Buale [Bole] and there is practically none within a 15 mile radius of Buale [Bole]" (Henderson in Stahl 2001, 193). The British army established a base at Bui in Banda just south of the Black Volta River to staunch the flow of trade goods north to Samori. Their efforts eventually expelled Samori and brought peace to the area by 1898. After the dust settled, many towns were left ruined, and grain, cattle, sheep, and even wild animals were scarce (Stahl 2001, 96-98, 193-94).

How did people manage to get by during these turbulent, dangerous times? We can reconstruct some of their experiences through the archaeological record left behind at Bui Kataa, the remains of the village of Bui, occupied during and immediately after Samori's defeat. Bui is strategically located along the shores of the Black Volta River (introduction, map 2). Though the site is now submerged by the reservoir created by the recent construction of the Bui hydroelectric dam, archaeologists conducted rescue excavations in advance of the flooding (York 1965; BRP 2008). Due to time constraints these excavations were limited but they still provide glimpses into everyday life. People may have constructed homes to live in, as attested by the remainders of rectangular, beaten laterite floors uncovered in four mounds (York 1965). ${ }^{3}$ That people invested in house-building suggests that they had begun to return to life as normal, an improvement over the privations attested to at Banda Rockshelter (chapter 3). Domestic activities resumed as well, 
as attested by cooking and storage vessels as well as iron implements. People seem to have retained or acquired some items of value too, including glass beads and cowrie shells, both of which may have been curated for personal adornment and ritual. Cowrie shells were also recovered and may have served as currency, a practice eventually replaced by British coinage. A handful of these items were imported from European sources, including ball clay pipes, white ware ceramics, glass beads, and substances contained in glass bottles, like liquor or medicine. But life in Bui was not without its dangers. Gun flints, shell casings, and bullets speak to the need to defend the village from Samori. Not everyone survived, as attested by one burial that showed injury consistent with a violent death (BRP 2008; York 1965, 18-19).

Banda peoples would have been tasked with feeding British soldiers as well as themselves. People altered what they were eating to cope with the increased pressure on diminished food supplies. One of the sacrifices that people made was adopting staple crops that grew more quickly. Maize became the staple grain, and the indigenous grains pearl millet and sorghum were abandoned, at least temporarily. Cassava, a low-labor crop that was considered poor man's food on the coast (LaFleur 2012) and in Kintampo (below), may have also been a dietary mainstay, as it was in other instances of dislocation (Cordell 2003; La Fleur 2012; as well as oral accounts I recorded in 2009). Notably, Ferguson mentions that his troops were unfamiliar with this crop when they encountered it in their 1894-95 tour of the Volta basin, a wide area that includes Banda (Stahl 2001, 208). A shift in dietary staples is a significant change in daily foodscapes, since tastes and textures of less-preferred foods are a constant reminder of vulnerability and lack of choice. Under different circumstances, we might interpret a shift like this as simply the emergence of new food preferences, but in this context of uncertainty it seems likely that maize and cassava indexed lack of choice. Maize's short growing season permitted two crops to be harvested per year, meaning people could produce more food quickly. Cassava can be grown with little labor, and its cultivation is easily hidden in the bush. After the devastations of Samori's pillaging, these qualities were likely needed at Bui, especially as the British soldiers stationed there placed extra demands on local food supplies.

Particular tastes, textures, and smells serve as sensory cues to past events and experiences, and familiar foods may have provided some comfort during these uncertain times. Although people had to rely on less-preferred starchy staples, cooks may have prepared them into familiar textures. Maize phytoliths were found on two grinding stones, suggesting that this less desirable grain was ground and perhaps made into a familiar food like tuo zafi or koko (porridge). The advantage of foods like tuo zafi is that they can be made from virtually any starchy flour into a culturally recognizable dish (chapter 5 ).

Although their choices were limited, cooks used familiar ingredients when possible. People seemed to have returned to eating familiar wild plants in their stews and soups, instead of the experimental variety attested to in oral 
histories and at Banda Rockshelter (chapter 3). These include Ficus, Sida, Zaleya pentandra, and cheno-ams, although any of these may represent weeds instead of food plants (Abbiw 1990). One of these (Sida sp.) would have imparted a slippery texture to soups, a mouthfeel that has a long history in Banda. Smoking retained importance, judging from the presence of tobacco seeds and pipes, and may have provided relief during stressful times. Peppers (Capsicum), another vegetable from the Western hemisphere, squash (Curcurbitaceae) and Celtis integrifolia, a common wild fruit, helped provide dietary variety and spice.

People's meat consumption also focused on expediency. Fish were consumed in higher proportions than are attested to in all of Banda's millennium-long history (Logan and Stahl 2017, 1381). From their location at river's edge, Bui's inhabitants were well positioned to take advantage of this critical resource. As an importance source of protein, fish would have helped to even out uncertain access to domesticated animals and crop plants, and fishing placed fewer demands on labor during peak agricultural seasons. People consumed other kinds of meat that would have been easily accessed in the immediate environs of their settlements and fields, particularly rodents and birds (Logan and Stahl 2017, 1381). The focus on these less-preferred animals may have been a result of overhunting by Samori's troops, but it also suggests that people were reluctant to stray too far from the village. Wild animals formed an important coping strategy during this troubled time, as evidenced by the high density of their bones (Logan and Stahl 2017, 1382).

\section{COCOA NATION: CASH-CROPPING IN \\ THE BRITISH GOLD COAST, C. 1897-1930S}

The British extended formal rule to the Gold Coast colony beginning in 1897, just after British troops had routed Samori's soldiers. They quickly set out to develop the economic resources of their new acquisition, particularly since it was expected to be self-financing, a policy Sara Berry (1984) termed "hegemony on a shoestring." A main thrust of their effort was in expanding trade in commodities already of interest, such as gold; a second thrust was the production of profitable export crops to fuel the machines and tastes of Europe. Starting in the early nineteenth century, the production of palm oil for export had been one of the earliest and most profitable readjustments to "legitimate trade" ushered in by the abolition of the slave trade. However, by the 1860 s, alternate sources of oil had been found for European cosmetics and industrial applications and caused a depression in the price of palm oil. Rubber served as a substitute export crop in the 188 os and 1890 , followed briefly by coffee, but cocoa became the dominant export crop in the early twentieth century (Grier 1981, 32).

Cocoa exports grew very rapidly from their meager beginnings in 1891, when exports were worth just $£ 4$, to account for half of the colony's exports by 1911, with Ghana becoming the world's largest producer by 1919 (Gocking 2005, 47; Grier 1981, 32). The rapid expansion of cocoa production was to have dramatic 
implications for the nature of land tenure, labor migration, and the geography of economic development in Ghana (Hill 1963). The push for cocoa production was so great that many farmers in southern Ghana reduced or abandoned the cultivation of food crops, so that they came to rely on imported European foods in the early twentieth century. This was to have major implications when cocoa prices declined, leaving smallholder farmers open to considerable risk (Grier 1981, 32-34). Areas north of the cocoa belt, like Banda, continued to focus on subsistence crops, according them perhaps a measure of resilience, though they faced their own set of challenges.

By 1900, cocoa production had expanded to such a degree that acute labor shortages resulted. The colonial government found a solution by declaring the newly annexed Northern Territories - the land north of the Black Volta River-a labor reserve for both Ashanti and the Gold Coast colony (map 5). The resulting outmigration of able-bodied men to work in cocoa farms and gold fields in the south diminished agricultural production in the north. The rise of this migrant labor force also helped facilitate the penetration of the Northern Territories with goods from the metropole, another central goal of the British colonial administration. This had the dual if not altogether intended effect of eroding the selfsufficiency of subsistence farmers, thus making it necessary for them to earn wages through migrant labor to support their families in the north. The import of British manufactured goods also led to the collapse of many local industries, such as iron, ceramic, and cloth production (Grier 1981, 24, 37-38).

As part of the development of markets for British goods, colonial officers sought to monetize their colony under a uniform currency. Adoption of a new British currency instead of local cowries would presumably pave the way for the acquisition of British goods. One way in which this was accomplished was the requirement that taxes, fees, and fines be paid in British currency. While the adoption and accumulation of such currencies were slow and uneven across the territory, they had major impacts on socioeconomic organization and agricultural production (Guyer 2004; for Banda, see Stahl 2001, 99-101). One of the simplest ways for rural people to gain access to cash was through the sale of local products, particularly surplus agricultural products or cash crops and craft goods like pottery (below; Stahl and Cruz 1998). Over the long term, imported goods transitioned from the realm of desired goods to necessities. The selling off of agricultural surplus, instead of storing extra grain for use later in the year, probably played a major role in creating the hungry season gap that is now so widespread throughout the continent, a thread I explore through Banda's experience below.

While the Gold Coast colony and Ashanti were undergoing rapid development, particularly in transport networks, little effort was expended on extension of transportation networks to the northern half of the country. Though colonial officers experimented with the production of cotton, shea nuts, and other locally grown commodities in the north, most of these ventures failed because of the high transport costs to the coast. A visit by W. Tudhope, the director of agriculture, to 
the Northern Territories in 1912 recorded local production of cotton, and determined that the price that growers obtained locally could not be matched if cotton were exported to London. Though alternate varieties and methods could be used to increase yields, prohibitive transport costs prevented the export of low-value, high-bulk commodities. At a cost of $£ 12.10$ per ton, the price of canoe transport from the north to the coast (Tamale to Ada) was still over five times that from Ada to Liverpool. Tudhope's assessment concluded that "until a satisfactory system of transport is evolved the profitable development of almost every purely agricultural product is doomed to failure" (ADM 56/1/153).

The opposite was true of the forested southern half of the Gold Coast, where the natural distribution of valuable raw materials like gold and kola coincided with the humid conditions needed to produce the most valuable export crops: cocoa, oil palm, and rubber. The area also benefited from close proximity to the coast and more developed transport networks (Cardinall 1931, 82). Colonial agricultural policy was therefore directed at exportable commodities in the south. This resulted in so-called underdevelopment of the northern half of the country, which was effectively cut off from production of the most lucrative goods and was too far distant to make a profit from lower-value crops, given the high transport costs to the coast (Plange 1979; Sutton 1989).

Besides subsistence agriculture and craft production, the primary productive roles of people in the northern half of the country in precolonial times had been as trade intermediaries, particularly in livestock and kola nuts. Indeed, caravan tolls and market dues were the primary sources of income for the British in these areas in the beginning of their tenure there. However, the colonial administration soon sought to redirect trade through their own newly established administrative centers, such as Kintampo (below), in part by closing local markets. This, along with the coerced outmigration of men, had the effect of closing off market access to many who had formerly produced cash crops like peanuts, cotton, and rice for local sale (Plange 1979, 8-9). Though the British made some attempts to stimulate trade, such as abolition of the caravan toll in 1908, they showed little interest in the commodities actually being traded in the north after several failed experiments indicated that their international export would not be profitable. Thus, the cycle of "nondevelopment" of the north was constructed, whereby transport networks were not developed because there were no low-bulk/high-value goods, effectively preventing export of high-bulk goods since effective means of transport were lacking (Sutton 1989).

\section{"GROW ENOUGH TO EAT AND TO SELL": BANDA IN THE EARLY COLONIAL PERIOD}

Following the British-led expulsion of Samori, and after many years characterized by multiple relocations, Banda peoples resettled their former villages, including 
that of Makala (Kataa), a period referred to archaeologically as the Late Makala phase, from about 1897 to the late 1920 s (Stahl 2001, 189). In some ways, these occupations were shells of their former selves. The village of Makala was much smaller than it had been in previous generations, at seven and a half hectares or fourteen American football fields in extent (compared to eighteen hectares in the Early Makala phase). Instead of the strong, thick-walled coursed earthen architecture of previous centuries, houses were built quickly using wattle-and-daub or pole-and-daga construction (Stahl 2001, 200). Although people had finally returned home after decades of instability, shifts in other kinds of routinized daily practices suggest that people did not inhabit spaces as before. For example, people disposed of trash differently, spreading it across the site and filling in depressionlike pits rather than setting aside certain areas for accumulation (Stahl 1999b, 58-61; Stahl 2001, 200, 203). Changes like these may well have stemmed from decades of migrating, of inhabiting spaces in other peoples' territories, of living life ephemerally, as well as from the significant demographic and economic shifts associated with colonial rule.

Since Banda was situated in woodland savanna too dry for cocoa production, colonial policy and investment in the area was, as in the most of the rest of the Northern Territories, minimal. There were few British officers in the Northern Territories - just eighteen in 1905- and little was known of the Banda area. A complete village inventory, for example, was not accomplished until 1917. Attempts to mine gold or cultivate cotton as a cash crop were met with disappointment, due in part to the high cost of transporting bulk goods southwards (Stahl 2001, 194-95). The lack of direct colonial intervention might be taken to mean that colonial impacts on food and agriculture were minimal in areas like Banda, but the evidence at hand suggests otherwise. Banda's story demonstrates how important it is to look at everyday responses to colonial rule in addition to the policies of the metropole themselves. Two trends evident in Banda's material record correspond with major dietary shifts: a significant gap in labor availability, particularly of men, and increased incorporation into the market economy. In this section, I evaluate both of these shifts and their impact on foodways. A more complete rendering of daily life under colonial rule and the wider political economic context can be found in Stahl (2001, 189-214).

British officials who visited Banda in the early 1900 s remarked on the low population density and generally inferior standard of living in the area. A 1907 tour of inspection by F. Fuller, the chief commissioner of Ashanti (of which Banda was now considered a part), describes the general conditions at the time:

The country is generally open and undulating; population scarce and of a lower standard from the Ashantis (if judged by their material surroundings), but more genial and docile than the Ashantis proper .... the tribe was unfortunately situated and suffered long from the slave raids of the Ashantis as well as from the more recent, and more thoroughly destructive expeditions of the Freebooter Samori-No 
wonder therefore that their numbers are comparatively few for the land they occupy and their villages small, ill-kept and generally inferior. The Pax Britannica has, however, already produced a universally beneficial effect and if the number and the condition of the children may be considered a criterion of the future condition of the race, it can be confidently asserted that the Bandas will rapidly attain prosperity. ${ }^{4}$

Colonial sources suggest that even in 1926 population densities were still quite low in Banda and the wider region (Stahl 2001, 198; Stahl and Anane 2011); a 1931 census puts population density in the wider region at zero to ten persons per square kilometer, among the lowest in the country (Cardinall 1931, 157). In a culture where wealth was very likely in people and the diverse skill sets they possessed (Guyer and Belinga 1995), these losses probably had a major impact on social and political life.

A lack of labor was of special concern to Banda's leaders during the early colonial period. Compounding low populations in Banda, colonial officials at the district capital of Kintampo requisitioned both food and labor from Banda, though Banda peoples were not always able or willing to fulfill those requests. For example, at the opening of the twentieth century, Banda was required to supply the district with forty-two to eighty carriers per month (Stahl 2001, 196). In 1901, the Banda chief complained that "the farms suffered in consequence of their absence, and that they themselves returned very thin and pulled down, unable to do a day's work for a considerable time afterwards" (ADM 56/1/415). While the chief may have overstated these complaints, taking men away from their farms probably did have a negative impact especially during key points in the growing season. Demands for food may also have increased over time; for example, in 1926 Banda was expected to help provision a considerable number of soldiers at Bui (Stahl 2001, 196).

People used numerous strategies, attested in the material and ethnohistoric records, to help cope with low population densities and limited labor availability. Family histories suggest that Banda families incorporated refugees and captives from different ethnolinguistic groups, which may have helped ameliorate low populations. For example, four of the seven families that founded Banda-Ahenkro, now the seat of the paramount chief, originated in ethnolinguistic groups other than the Nafana (e.g., Gonja, Gyaman). Although the chieftaincy in Banda was Nafana, in practice it comprised individuals from several different groups who adopted Nafana customs (Stahl and Anane 2011; Stahl 1991; Stahl 2001, 198-99; see also Whatley and Gillezeau 2011 on this general phenomenon).

Another strategy involved significant changes to the gendered division of labor and the crops cultivated. Both colonial demands for labor and the increasing need to access cash through labor migration would have disproportionately drawn men away from their homes and fields (Cruz 2003; Stahl and Cruz 1998, 216; Stahl 2001, 207-8). Women and elderly men potentially would have taken on a much greater share of the responsibility for making ends meet and feeding their families. In Banda, people shifted to eating maize as a staple grain (19\% ubiquity), with smaller 
amounts of pearl millet present (12\% ubiquity) and sorghum absent entirely (see appendix B). Although food preparation remains difficult to access in the material remains, charred plant remains are much sparser than in previous centuries, a change which may have resulted from an increased focus on cassava (see below) and/or from changes in food preparation. ${ }^{5}$ It is quite possible that women abandoned grinding grains on stones in favor of the wooden mortar, which was better suited to pounding maize and cassava and remained the dominant preparation method well into the twentieth-first century. Remains of two types of wood used to make mortars have been identified in the archaeological record at the same time that grinding stones disappear (Logan and Cruz 2014, 222). ${ }^{6}$

These shifts in agricultural production and possibly food preparation coincide with changes in pottery production, which ethnohistorically was the domain of women (Stahl and Cruz 1998). Potters increasingly used maize cobs to roll texture onto pots, a shortcut that avoided more time-consuming decoration techniques (Logan and Cruz 2014). The diversity of decorative treatments and combinations also declined (Cruz 2003). Differences in temper in the archaeological ceramic assemblages are consistent with a pattern of reduced effort in pottery production, and perhaps increased use of wooden mortars in food and ceramic paste preparation. While all of these changes may relate to an increasing need to trade ceramics at colonial markets, they also suggest that women needed to make pots faster (Logan and Cruz 2014, 224).

Traditionally male activities diminished during the same period. Iron-working, typically a domain of men (Stahl 2016), was no longer practiced, with people instead acquiring already finished items and recycled iron from regional sources and the British metropole (Stahl 1999b, 64). Hunting, also usually a male domain, was considerably attenuated compared to Banda's earlier record, though broadly consistent with patterns in the late eighteenth to early nineteenth centuries (chapter 3; Stahl 2001, 207). Meals were less meat-focused than in previous centuries, as attested by the low density of animal bones overall (Logan and Stahl 2017, 1383). People did not eat bovids like cattle, sheep, and goat in the quantities they used to, perhaps because they were more valuable as trade goods. More difficult-to-capture animals like carnivores disappeared, suggesting the absence of skilled hunters or of the time to pursue difficult hunts (Logan and Stahl 2017, 1387), or a landscape denuded of fauna as a result of overhunting by Samori's hordes. People increasingly made up the bulk of their meat needs with animals like rodents and reptiles that could be easily captured nearby as pests in agricultural fields or villages (Logan and Stahl 2017, 1385). These kinds of changes often reflect periods of food insecurity or other stress, when people struggle to fill dietary needs with what is most accessible.

Taken together, these shifts point to women taking a larger share of responsibility in farming and in making ends meet. In Cameroon, Guyer (1978, 1980) also found an increase in female farming in association with colonial demands on 
men's labor. In Ghana, men were required to serve as porters and other posts by colonial governments, and were encouraged to migrate southwards to earn cash as laborers on cocoa farms and in gold mines (Cruz 2003; Grier 1981; Hill 1963; Stahl and Cruz 1998). This emphasis simultaneously removed men from family labor obligations and firmly installed the infrastructure of the market.

Lower availability of labor must have taken a toll on the amount of land people were able to farm, and it reduced the quantities of food people were able to produce. In this low-labor context, cassava makes the most sense as a replacement crop, because it produces exponentially more calories per unit labor than any grain crop (Jones 1959). While cassava is hard to recover archaeologically, archival sources reveal that it was present in the broader Volta basin by 1894-95 (Stahl 2001, 208). We also know that cassava was widespread in Kintampo, the market town visited by Banda women, by 1902, where it was considered "poor, coarse food" (ADM 56/1/458). Both of these earlier indications, in addition to the changes in food preparation mentioned above, suggest that cassava was also in Banda at the turn of the century. Archival sources reveal that cassava was widespread in Banda by 1931 (BRG 28/2/5). Although we cannot definitively say when cassava became a staple in Banda, it seems unlikely to have been chosen out of culinary preference. Instead, Banda's adoption of cassava indicates the consumption of a less-preferred food associated with poverty, and provides another line of evidence for the food security challenges people experienced during the first few decades of the twentieth century. Cassava continues to provide cheap and accessible calories in Banda today, where its consumption has increased markedly in recent decades (chapter 5).

Although maize may have reduced the time spent processing and preparing food, compared to cassava it was quite expensive to produce if measured in calories produced per unit labor (Miracle 1966). Thinking more broadly, there are several additional factors that might explain maizes increased importance in Banda, including changing tastes as well as the desire for a fast-growing crop that matures during the hungry season. Maize might have been considered more desirable than in previous centuries, although there are no clear indications that this is the case. The co-occurrence of cassava as well as the consumption of low-ranked animals suggests that at least some people in Banda may have not been able to consume preferred foods. The distribution of maize across archaeological contexts is not restricted as in early periods, so it seems unlikely that maize was a food enjoyed only by elites or other special groups. Maize's use as a staple probably has much more to do with its ability to produce a harvest quickly, before yams and grain crops are ready to harvest. Only fast-maturing pearl millet can produce a crop in as little time as maize, but millet requires a much greater expenditure of labor for cultivation (Miracle 1966) and processing. What is perhaps most significant about maize's quick maturity is that it becomes ready to harvest during the worst part of the hungry season, when food supplies from the previous year's grain harvest are 
often depleted and just before yams are ready to harvest. For these reasons, maize is in many ways a barometer of the hungry season, and its proliferation in late nineteenth- and early twentieth-century Banda suggests that this particular kind of scarcity may have become more pronounced at this time.

Why might the hungry season have become more marked at this time? I suspect it has much to do with the increasing entrenchment of market economies, a complex dynamic that requires some unraveling. Food was required to supply growing populations of nonfarmers in colonial centers (Guyer 1978). Banda, for example, was expected to supply food to Kintampo, the district headquarters (ADM 56/1/458; Stahl 2001, 196). Selling agricultural produce was also one of the few ways in which rural villagers could access cash. Yet these demands on food supplies came at the same time that labor was in short supply, and agricultural production was likely at its lowest, as Banda peoples resettled in the area after decades of dislocation. Even if families could have stretched already diminished food stocks through the year, the need to sell a portion of their harvest would have drastically reduced their ability to feed themselves. This tension may have been why rural people were reticent to supply Kintampo's market (Stahl 2001, 196).

These dynamics may have resulted in the entrenchment of the hungry season gap, which is often assumed to be a natural feature of African agricultural cycles. The hungry season gap occurs during the growing season, when last year's harvest runs short and the current crop is not yet ready to harvest. Prices for food are high at this time, since demand for food is also high, a dynamic which is observed in monthly records of food prices in turn-of-the-century Kintampo (ADM 56/1/415). In May 1901, the beginning of the growing season, a colonial officer notes that there "is very little food" in the district. By July 1901 the prices of food had gone down a little, with only "Kassava [sic], young corn, young yam, and spinach" being available at reasonable prices. Note here that it was American crops, maize and cassava, that were available, as well as young yams that had probably not reached their full size. By August/September, prices were half what they had been just months earlier, and there was a much wider diversity of foods available, including plentiful yams. This description of food availability and pricing follows the growing season of African crops, and indicates a lack of food in the early growing season known as the hungry season gap. While people with means, such as the British authors of the report, could have afforded to pay twice as much for food, villagers would have been especially hard pressed to make ends meet.

Women may have been active in mobilizing their social connections to help deal with seasonal food shortages. One place we can trace these networks is in the pottery women produced and consumed. The movement of pots, from producer to consumer, signals economic and social relationships. Sourcing studies of pottery found in Banda at this time indicate a greater variety of production centers from both east and west of the hills. The most abrupt change is a shift away from acquiring vessels made on the west side of the hills and increasing consumption of vessels 
from closer contacts on the east side. These patterns may relate to continued risks and uncertainty in traveling to and from the west, or to the influx of new refugee potters (Stahl 2001, 205-6; Stahl et al. 2008). In any case, they also signal exchange among a closer set of women and men, with whom face-to-face interactions were more common. Food may have been a central part of these relationships. Ethnohistorically, pots were often bartered for their volumetric equivalent in foodstuffs. Producing more pots may have provided a means to access food supplies in lean times. Building these relationships with smaller, more intimate networks would have been an excellent social strategy, since people are much more likely to share food with people they know and can call upon in later times of need.

The British were actively engaged in creating markets for their manufactured goods, a process that was seen as not only benefiting the Crown's coffers but also acting as a stimulant to improve agricultural production in the colonies. Cash was required to purchase such goods, and for most rural people outside major cashcropping zones in the south, growing enough agricultural surplus was the primary means to access it. W.S.D. Tudhope (ADM 56/1/153), on a 1912 tour of the Northern Territories, including areas immediately across the river from Banda, described these hopes:

A desire for money appears to have been awakened and they are beginning to realise the additional luxuries that money can provide for them. This indicates probably a surer sign than any of the possibility of a further development in Agricultural productions, - the only source of wealth open to them in their own country. Many of their young men against the wishes of their relatives have left the country to hire themselves as labourers which they would not do if they could get remunerative employment at home... A considerable proportion of the male population are employed on transport and other Government work...

Yet while hoping the desire for consumer goods would stimulate production, Tudhope himself also acknowledged the futility of this endeavor due to high transport costs (above). The potential for cash cropping was explored in all corners of the Gold Coast, and most studies of the Northern Territories came back with assessments similar to Tudhope's. ${ }^{7}$ Numerous sources attest to the growing of cotton in the Banda area beginning in 1904 (ADM 56/1/421), though the origin of its cultivation was probably much older. In 1928, colonial officials evaluated Banda and areas west for the production of cotton as a cash crop, but were sorely disappointed regarding yields, since cotton was intercropped. Farmers were resistant to growing monocrops of cotton, and the British soon abandoned the idea. Instead, they favored the production of groundnuts (peanuts), which were produced in enough quantity to be sold at market (BRG 28/2/5). Other than encouragement of these two crops, as well as urging Banda farmers to supply the Kintampo market with foodstuffs, there seems to have been little direct colonial interventions in agriculture in Banda before 1930. ${ }^{8}$ 
Yet the indirect impacts of market policies and monetization were pervasive. Selling off agricultural produce to local markets was one of the few ways in which rural people could access much-needed cash. This meant that people had to "grow enough to eat and sell," a phrase used today to describe the most common strategy for accessing cash (chapter 5). Until recently, farmers have focused on growing subsistence crops, hoping their harvests will be of sufficient quantity to not only feed their families but also sell at market. But harvests are rarely sufficient for this purpose, at least on any sustainable scale, and certainly production on this level would have been difficult if not impossible given low labor conditions in the early colonial period. A surplus harvest one year may be followed by a deficit the next, and the margin of surplus is often so tiny that it does not account for the need to purchase foodstuffs at high prices during the hungry season.

Cash was needed not only to purchase items at markets but also, increasingly, to pay taxes and other colonial obligations. The British actively engaged in creating local markets for their manufactured goods, initially stocking government stores with these items to encourage desire for them (Stahl 2001, 195). In the first decades of colonial rule, the largest and closest market town and colonial center was Kintampo, just under eighty kilometers away, about a two- or three-day walk; later Wenchi, which is slightly closer, became the district center. People from Banda would have had to go to Kintampo to conduct official business like court cases, and to reach a wider market for their wares. Archival sources suggest that Banda women sold their goods there on an occasional basis (ADM 56/1/415).

What was available in Kintampo, and what of these items did Banda peoples choose to purchase? A brief survey allows us to indirectly assess the degree to which Banda's inhabitants were integrated into the British colonial market economy. In 1901, Kintampo's market offered cloth, basins, pans, knives, fezzes, wooden pipes, towels, pomade, snake beads, looking glasses, combs, matches, sugar, brass and copper rods, lead bars, and soap (ADM 56/1/415). Several of these items and more are found in Banda's refuse piles, attesting to the replacement of some local industries with imported alternatives. European-made ball clay pipes were among the first imports to be used regularly, and they soon replaced local alternatives (Stahl 2001, 206). Pipes may have also been obtained through barter-perhaps of tobacco, which we know Banda peoples exchanged at the Kintampo market (below) (Stahl 1999b, 63, 70).

Banda peoples enjoyed other imported substances like bottled spirits in some quantity. Medicines and pomades were also consumed, as attested by a smaller quantity of milky, clear, and blue glass. These objects stress the global connectedness of places like Banda, probably mediated through the market at Kintampo (Stahl 1999b; Stahl 2001, 195-96, 209-11). These items suggest that Banda villagers were able to obtain petty cash, probably through trade of local produce such as tobacco, groundnuts, or cotton. They also suggest elaboration on existing tastes for body oils (Vaseline, for example, may have been a stand-in for local shea 
butter), for new medicines to cure ailments of the elderly, and for alcohol, the consumption of which was taken up with gusto for reifying the authority of chiefs (Akyeampong 1996; Stahl 2001, 209-11; Stahl 2002).

Imports may also have provided convenient replacements for labor and skills that were diminished after Banda's demographic collapse. Manufactured ointments would have saved women a lot of work, as shea nuts can be time-consuming to collect if the stands are far away, and the oil is laborious to extract and process. Imported alcohol may have also released women from the need to produce large quantities of beer. The presence of imported metals like iron and brass (Stahl 1999b, 64,70 ) might have helped make up for the lack of men with either the knowledge or time to produce these items at home. Other items, like gunflints, present even earlier than the colonial period, attest to the introduction of new technologies that spread rapidly and had major consequences for hunting and warfare (Stahl 1999b, 70).

Still other industries proved resilient against imported alternatives, particularly ceramics and cloth. Although imported vessels were readily available, as attested by the very small amounts of imported white ware and a metal enamel vessel present in the material remains (Stahl 1999b, 64), Banda specialists continued to practice potting and most people used these local pots (Stahl 2001, 207; Stahl et al. 2008), as discussed above. People also continued to produce cloth locally, instead of switching to the manufactured alternatives that were rapidly making inroads. Although Banda peoples controlled the entire supply chain for cloth, from farming cotton, to spinning thread, weaving, and dying, the scale of production appears to have been limited to household-level production (Stahl and Cruz 1998). One of the main challenges in estimating scale is that spindle whorls are often curated and passed down from mother to daughter, thus they rarely appear in the archaeological record (only nine are present in Late Makala contexts; Stahl 2001, 204). One seed that is likely indigo was recovered, not far from a feature that resembles a dye pit (Stahl 2001, 203).

Yet other imported goods simply replaced items formerly imported from elsewhere, though not without consequences for how they were used. Beads are a case in point, since they had long been acquired from some distance away (chapter 2; Stahl 2001). In Late Makala times the source of these beads shifted, with about half of those recovered coming from Europe. Some of the more exquisite multicolored hand-drawn and wire-wound forms, which resembled earlier forms, were used in sacred contexts like nubility rites. Cheaper, mass-produced monochrome forms were also adopted and used for more mundane purposes (Stahl 2001, 211).

The market also provided opportunities to access other kinds of food from a wider world, and attention to it brings into focus the foodscape of central Ghana, even if Banda diets were probably considerably more provincial. In 1902, British doctor W. Graham meticulously documented the foods available at Kintampo (ADM 56/1/458). The Hausa, an ethnic group originating in Nigeria and apparently 
working for the British at Kintampo, preferred maize in the form of kenkey, a fermented dough wrapped in leaves. Other African groups did not like the sour taste of kenkey and instead preferred fufu, preferably made of yams but sometimes plantain, cocoyam, and/or cassava. Even today, while people in Banda have now developed a taste for kenkey, most women do not make it regularly at home.

In Banda, fufu made of yams was probably preferred as it was in Kintampo and continues to be today, but in practice this dish was probably also made out of cassava. Fufu is a seasonal dish whose consumption is linked to the availability of yams, starting in August until they are finished. Cassava, however, can be obtained year-round, and would have extended the seasonal availability of this dish. Tuo zafi made of maize and pearl millet likely formed the dietary mainstay of people's diets in the dry season and early wet season (November through July). Cassava can also be ground into a flour and used to make tuo zafi. Graham does not mention this northern dish at Kintampo, but its preparation and widespread consumption is well attested in Fortes and Fortes's (1936; see below) ethnography of the Tallensi in the 1930s as well as in oral accounts from Banda (chapter 5).

Each of these starchy staples is served today with what in Ghanaian English is called "soup," a phrasing and culinary grammar that was also common in turnof-the-century Kintampo. This "soup" is more akin to a thin sauce in American English usage. People particularly enjoyed peanuts, prepared into a soup or simply roasted. While peanuts have not been attested in Banda's archaeological record, Russell (BRG 28/2/5) notes that they were cultivated as a cash crop there, perhaps for trade at Kintampo; it is unclear whether people commonly consumed peanut soup. Other soup ingredients were common at Kintampo, including the leaves of the sweet potato plant, tomatoes, okra, and eggplants. Soups were flavored by local ingredients like gabu, pulverized onion leaves, and dawadawa balls, both recalled with fondness in oral food histories in Banda and likely available in the early twentieth century (chapter 5). Other spices sold at Kintampo included a local variety of ginger, chili peppers, black pepper, and melegueta pepper. The range of soup ingredients found in Banda's archaeological record is much smaller, though this is probably a function of preservation rather than a lack of availability or preference. Okra and several wild leafy greens (Cassia spp., Portulaca spp., Zaleya pentandra, and cheno-ams) were found in trash deposits, suggesting the continued preference for a slippery texture as well as the taste and nutritional affordances of wild greens.

Many different kinds of beans were available, chief among them cowpea, also identified archaeologically at Banda, and Bambara bean. In Kintampo and probably in Banda, most women used shea butter for cooking, though palm oil was available for those with the taste and means to access it. A wide array of tropical fruits were also available, including pineapples, limes, oranges, bananas, mangoes, and papayas, several of which can also be grown in the Banda area. Tobacco was among the market's popular items (ADM 56/1/458), and it was certainly consumed by Banda peoples judging from the prevalence of tobacco pipes. 
Sorghum was also widely cultivated near Kintampo and prepared into porridge or pito, a local beer (ADM 56/1/458). Beer brewed of an unspecified grain was made locally according to reports of the 1906 trial of Adjua of Banda, who was charged with poisoning her brew to murder another woman (ADM 56/1/421). Pito is today made out of sorghum, but sorghum disappears from the plant repertoire in Late Makala deposits. This may simply be a preservation issue, or beer may have instead been made from pearl millet or maize, as is occasionally done elsewhere. Stahl $(1999 b, 69)$ suggests that the intrusion of foreign beer and spirits may have eroded local beer production, though Adjua's story suggests that it was still common enough, and indeed it continues today.

It is difficult to evaluate how these shifts in food availability and access might have influenced people's health and well-being. While such information can be gained from human remains, per an agreement with local Banda communities we do not exhume ancestors during the course of archaeological investigations. However, height data suggest that food deficiencies occurred elsewhere in the colony during the early colonial period in particular. Height is not a perfect indicator of health and nutrition; it relates most strongly to protein consumption. Austin and colleagues (2007) found a significant decline in heights in people born in Ghana between 1895 and 1909. While correlation is not causation, it is worth noting that the early part of this time frame encompassed three wars between the British and Asante, as well as the British taking formal control of the new Gold Coast colony in 1901. Violence often leads to severe food insecurity, as the Banda data also suggest. But these effects persist well into the first decade of the twentieth century, long after the cessation of direct violence. Note that this period corresponds precisely to when we see Banda's inhabitants switch to maize as a staple, in the period encompassing the 1890 os to 1920 s. One of maize's primary roles in modern West Africa is in plugging what in the twentieth century became known as the hungry season gap, given that it matures precisely when people run short of last year's harvest. A significant decline in height, as proxy for health, as well as the switch to maize as a staple in Banda in the 1890s-1920s-just as colonial officials were forcing engagement with cash-may well signal that the hungry season gap had become a more or less permanent feature of agricultural cycles in affected areas by this time.

\section{SCIENCE AND THE “DISCOVERY” OF MALNUTRITION IN THE LATE COLONIAL PERIOD}

For many decades, the challenges of feeding one's family were simply beyond the gaze of the colonial government, but this began to change in the interwar period (Worboys 1988). This policy shift was coincident with growing faith in the use of science to understand and improve the welfare of the colonial citizenry (Hodge 2011; Tilley 2011). In British Africa, these developments were closely linked to changing perspectives on the role of the colonial state as well as African labor. 
Labor had long been a limiting factor in the continent, and it was thought that improving the health of Africans might help increase the quality and size of the labor force. How these changes in policies played out on the ground varied (Iliffe 1987; Tilley 2011). In many colonial contexts, malnutrition was framed as a scientific problem rather than a symptom of the political economy of colonialism, a view which continues to resonate in many development circles and has the effect of depoliticizing food distribution. Other colonial settings, the Gold Coast among them, mostly ignored the growing evidence of malnutrition in their colonies and did not enact comprehensive nutritional policies (Robins 2018, 168).

In the Gold Coast, Africans residing on the coast were more accessible to the colonial gaze, and some of them consequently came under closer scrutiny. By contrast with the north, there was abundant food in the south, but food costs there were high. For urbanites with steady employment, wage increases made up for increased food prices. At the same time, food imports, particularly of rice, flour, and tinned meat, fish, and milk, were on the increase (Robins 2018, 170). Literate urban Africans enjoyed these high-status foods and consumed them in abundance. The colonial government should have been pleased by this development, since it meant they earned more on imported food tariffs. But instead, beginning in the 1920s, they attacked African consumption of imported foods as a lazy, unhealthy habit (Robins 2018, 171). One can only speculate as to why colonial officials critiqued Africans for eating the same foods that the British did, but I suspect it has a lot to do with policing of racial boundaries. In response, numerous attempts were made to increase the consumption of local foods among African elites. This was done under the guise of improving health, since imported foods were deemed less nutritious (Field 1931; Robins 2018, 172-73). Still, agricultural policy in the 1920 sold Coast remained focused on cash crop production (Robins 2018, 174).

In 1926, William Ormsby-Gore, undersecretary of state to the colonies, toured West Africa and vocalized concerns that cash cropping had been too successful and had reduced the arable land devoted to food crops. He was concerned with the nutritional quality of foods, and like his counterparts in the Gold Coast expressed growing concern over Africans' consumption of imported foods. To him, a nutritious diet was critical for nurturing a productive labor force. He promoted the idea that food should come first, and economic concerns second, though his connection of diet to labor reveals that economic concerns remained paramount in his thought process. Growing concern with African welfare among reformist groups in Britain in the 1930 s led to the establishment of the Committee on Nutrition in the Colonial Empire, which published a 1939 report declaring that there was no major food shortage in the British Empire. Instead, Africans' poor nutrition was blamed on African laziness and the lack of variety in their foodways-in short, a poor diet was their choice (Robins 2018, 175).

Given the time and effort expended to alter the diet of the urban African elite, who did not suffer from food insecurity, one might expect at least similar attention 
to the diets of the poorest Africans. This did not happen until the 1930s, when new scientific methods in the form of the nutritional survey led to the discovery of malnutrition in the colonies (Worboys 1988). In the Gold Coast, medical officer F.M. Purcell was tasked with making a nutritional survey of the entire Gold Coast. His grisly 1939 illustrated catalog of deficiency diseases near Akim, in forest country, connected these ailments to nutrition, and showed the impact of high food prices on the rural poor. In subsequent drafts of his national survey he found widespread nutritional deficiencies in the Northern Territories, where people were lethargic due to low food intake during times of "mild famine" (the hungry season) and suffered frequently from scurvy. He characterized the Gold Coast as a whole as "poor in indigenous foodstuffs." Noting the importance of introduced foods like maize and cassava, he suggested the introduction of more foreign crops. To further improve nutrition, he thought women ought to be taught how to properly feed and cook for their families. He viewed pounded starchy staples like $f u f u$ with particular derision, noting that they involved very arduous work for women, and that their manner of preparation was nothing short of "violent," inducing of course equally untoward health effects (Robins 2018, 175-77).

Unlike his Akim work, Purcell's national nutritional survey, which reported severe malnutrition in the north, was never published; indeed, it was actively suppressed. A British official reportedly told him "no one may starve in the British Empire," revealing the colonial government's concern that the report would fall into the hands of the empire's critics. Purcell resigned in protest in 1943, but his findings and recommendations do seem to have had an influence on later developments (Robins 2018, 177). By the 1940 os and 1950s, the British colonial government promoted a Grow More Food campaign in the Gold Coast, and made food production a priority over cash crop production. Education campaigns for women were less effective, not because women did not readily take to their lessons, but because they preferred the taste of traditionally prepared foodstuffs. Many of these policy changes and recommendations were continued in the early years of independent Ghana (Robins 2018, 178-79).

During the same years, the science of anthropology was also employed by colonial governments as a means to understand their subjects (see Tilley 2011). The ethnographic work of Meyer Fortes and Sonia Fortes among the Tallensi in northern Ghana, published in 1936, helped to flesh out the local context of food shortages, which Purcell was unable to gather using nutritional surveys alone. Unfortunately, we do not have archaeological data available for the late colonial period in Banda, since those deposits are buried under modern occupation. The Tallensi study brings to life the experience of the hungry season for this far northern region, with implications for understanding life in Banda during these decades. I agree with Shaffer (2017) that these experiences should be evaluated in a highly localized fashion, so my description of the Tallensi should not be understood as an interpretation of Banda's specific circumstances, even though Banda was similarly situated in relation to the colonial economy and there are 
considerable similarities to recollections of "olden times Banda" (chapter 5). In particular, the drier environment occupied by the Tallensi would have afforded a much smaller margin of security than in Banda.

Among the Tallensi, the primary foods were pearl millet (early- and late-maturing varieties), sorghum, and sometimes rice. Maize was not grown locally but was consumed occasionally when it was available cheaply at market. The emphasis was on crops that matured at different times of year so as to insure the food supply year-round. Groundnuts were frequently cultivated and often sold, and appear to have been the only significant cash crop. Other crops included Bambara beans, cowpeas, Kersting's groundnut (Kerstingiella geocarpa), frafra potatoes (Coleus dystenericus), and sweet potatoes. Vegetables were the domain of women, and included naygena (Gyandropsis pentaphylla), okra, bet (Hibiscus sabdariffa), beris (H. cannibus), and neri seeds (Cucumis melo) (Fortes and Fortes 1936, 242-45). Meat consumption was limited and unpredictable, even if almost all households possessed fowls, most had sheep and or goats, and a few of the more wealthy households kept a cow or two. The animals were slaughtered rarely, particularly in the case of cattle, which served as bride wealth. Animals were viewed as mobile wealth rather than as providing a steady supply of meat, eggs, or milk. ${ }^{10}$ Shea butter was the only oil. Flavorings included dawadawa balls, red pepper (often imported), rock salt from the south, as well as ashes prepared from grasses and used as a salt substitute (Fortes and Fortes 1936, 248-51).

Fortes and Fortes (1936) portray Tallensi life as vulnerable and highly susceptible to famine. In their original article, they capture the food cycle in a two-column format that highlights the seasonality of food availability and some of the social strategies people used to access food in trying times. I reproduce this information in full detail in table 1 , because it captures the dynamics of food insecurity, which are best understood in a cyclical way (see also Mandala 2005).

Several elements of the Tallensi case study are pertinent to understanding the dynamics of food insecurity in the 1930 s and how people managed to avoid it. People employed a number of social and economic strategies to make ends meet. These strategies not only tell us how people survived, but also provide clues into the severity of hunger. We know from modern studies that people suffering from food insecurity employ a hierarchy of coping strategies (Devereux 2001; De Waal 1989). People preferentially use strategies that have only short-term impacts, and avoid doing things that will impact their long-term survival unless they are out of other options. In other words, people often choose to go hungry in the shortterm to preserve their long-term assets. Livestock are one of the most widespread long-term assets; they are usually not sold or slaughtered unless the owners are suffering from severe hunger. That Fortes and Fortes (1936) mention this method suggests at least some Tallensi were in a particularly bad state.

Given a choice, most Tallensi employed less costly economic and social strategies to mitigate food shortages rather than consume or sell off their long-term assets. If money or barter goods were available, people could trade them for grain 
TABLE 1 Tallensi Productive and Food Cycles in 1934 (abridged from Fortes and Fortes 1936, 253-59)

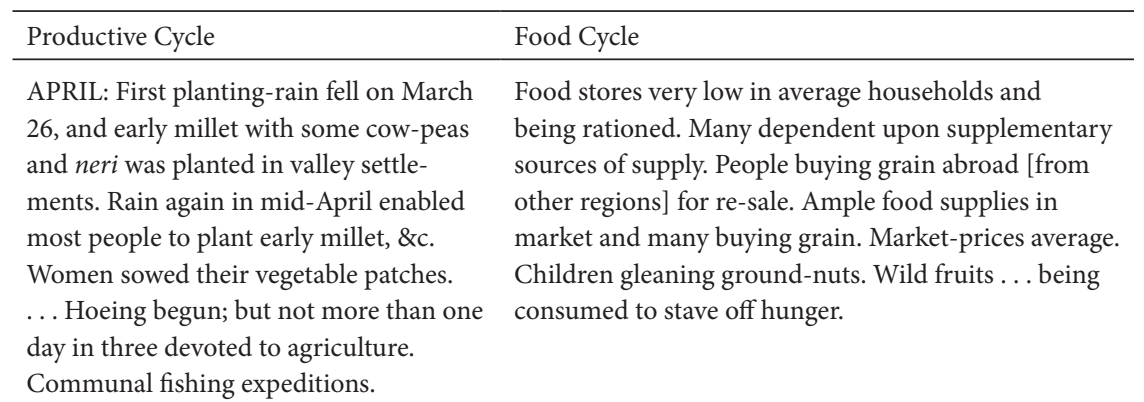

MAY: Rains continue erratically. Early millet planted in the stony and hilly areas. Others interplanting guinea-corn and some ground-nuts. Work on bush farms preparatory to planting commenced. Tempo of agricultural activity increasing rapidly.

JUNE: Height of agricultural season. Men completely absorbed in hoeing and weeding, planting guinea-corn and late millet on bush farms, rice, ground-nuts and minor crops. Hiring labour for help in hoeing and weeding...

JULY: Early millet harvested by those who planted first on valley land. Hoeing and weeding of compound and bush farms in full swing. Some still planting subsidiary crops. Poultry breeding begins.

AUGUST: Late planters harvest early millet. Invited collective labour for hoeing and weeding coming to fore, but hired labour still in evidence. Fresh hibiscus leaves used in soup.

SEPTEMBER: Harvesting ground-nuts and other subsidiary crops (roots and legumes) begun. Hoeing and weeding of bush farms continue. Women plucking green ocro and burning early millet stalks for bakaa [salt substitute]. Ritual festivals Food stores deplenished and severe rationing. "Hunger" $(k \supset m)$ commences. Poorer households suffer two or three days' hunger a week, living on vegetable soup, groundnuts and wild fruits. Householders send their wives to purchase grain abroad [from other regions] for consumption and re-sale if they have money. Many selling live stock bit by bit to buy grain in market. Prices of all commodities rising. Visits being paid to relations in more fortunate areas to get some grain.

Peak of hunger reached. Granaries empty among poorer households. Much live stock sold or bartered for grain very cheaply; grain scarce and dear. Much ground-nuts for sale. Small groups of children wander about hungry, feeding on wild fruits and small animals they find near the settlements. Towards the end of the month many people are staunching their hunger by cutting the ripe or half ripe heads of early millet which they roast on the embers and nibble at.

Early millet eaten by those who harvest. Relatives from the later-planting areas come to beg grain. Wild fruits still eaten and hunger prevalent in late-planting areas. Ground-nuts, beginning to ripen, plucked and chewed as snacks.

Almost everybody has early millet; hunger appeased for a time.

Those who harvested in July already reaching end of supplies of early millet, and resort to market and relatives. Early millet very expensive in market. New ground-nuts (partly green), roots, and legumes supplementing diet largely. 
TABLE 1 (Continued)

\begin{tabular}{|c|c|}
\hline Productive Cycle & Food Cycle \\
\hline $\begin{array}{l}\text { OCTOBER: Harvesting of guinea-corn, } \\
\text { rice, root crops, legumes, \&c., general. } \\
\text { Neri lifted. Women drying and storing } \\
\text { vegetables. }\end{array}$ & $\begin{array}{l}\text { Food becoming plentiful. Price of grain falling rapidly } \\
\text { in market. Cooked food cheap and plentiful in market. } \\
\text { Marriage season begins. }\end{array}$ \\
\hline $\begin{array}{l}\text { NOVEMBER: Harvesting late millet } \\
\text { on bush farms, cow-peas and Bambara } \\
\text { beans. Women burning valley grass for } \\
\text { ziem. Children gleaning ground-nuts in } \\
\text { play, not because of hunger. Height of } \\
\text { ritual festival season. }\end{array}$ & $\begin{array}{l}\text { All kinds of food plentiful. Harvest festivals, during } \\
\text { which enormous quantities of food are consumed and } \\
\text { circulated and many animals sacrificed, giving the } \\
\text { maximum meat supply of the year, and root crops in- } \\
\text { cluding purchased yams especially in demand for the } \\
\text { festivals. All foodstuffs abundant and cheap at market. }\end{array}$ \\
\hline DECEMBER: Agricultural work over. & $\begin{array}{l}\text { Height of ritual season: funeral ceremonies, children's } \\
\text { dedication ceremonies, many marriages; all involving } \\
\text { consumption of live stock and grain, in sacrifices, as } \\
\text { cooked food, and beer. }\end{array}$ \\
\hline $\begin{array}{l}\text { JANUARY: Period of secondary activities } \\
\text { such as housebuilding, cutting grass and } \\
\text { timber for roofing, handicraft work. Young } \\
\text { men begin to go abroad temporarily. }\end{array}$ & $\begin{array}{l}\text { Grain rationing again begins. Grain and other } \\
\text { foodstuffs, including imported maize, plentiful and } \\
\text { cheap at market. }\end{array}$ \\
\hline FEBRUARY: As in January. & $\begin{array}{l}\text { Grain issued for only one meal a day. Many purchas- } \\
\text { ing grain rather than using up their own supplies. } \\
\text { Ground-nuts and cow-peas regular and important } \\
\text { supplements to cereal food. Women finding grain to } \\
\text { augment supplies, by trading, etc. Market supplies still } \\
\text { plentiful, prices average. }\end{array}$ \\
\hline $\begin{array}{l}\text { MARCH: As in February. Sporadic } \\
\text { cleaning of fields and hoeing. }\end{array}$ & $\begin{array}{l}\text { Grain supplies sinking and more carefully rationed. } \\
\text { Children and women gleaning ground-nuts to stop } \\
\text { hunger. People going to Mampuru and Nabte countries } \\
\text { to purchase grain for re-sale. Grain still plentiful in } \\
\text { market, also other products, e.g. yams (imported). }\end{array}$ \\
\hline
\end{tabular}

at the market. Most often, this included selling value-added prepared foods like dawadawa powder, collected and cultivated vegetables, as well as peanuts, which were the primary cash crop. Livestock were bartered only if there was nothing left in the common stores. Grain was also rationed frugally to stretch out meager supplies, beginning often quite early in the season. Women with some means also often traveled moderate distances to barter for grain, which was then sold locally in both raw and prepared forms. Wild foods, like shea butter tree fruits, dawadawa, baobab, and Celtis integrifolia, were also important supplements (Fortes and Fortes 1936, 246-47). Importantly, many of these tasks involve the conversion of labor, especially that of women, into cash.

The food cycle relayed by Fortes and Fortes (1936) is depicted side by side with the productive or agricultural cycle, as the two are closely linked, but it would be a 
mistake to assume, as many scholars have, that the agricultural cycle is sufficient to explain the hungry season gap. Nowhere do Fortes and Fortes mention an absolute lack of food supplies in the wider region. Instead, these data also tell of another correspondence: between the price of food and the hungry season. Prices for food were higher, even double, during the hungry season months. High prices put food out of reach for the poorest people, who, as discussed above, used increasingly desperate strategies to access the cash needed to acquire food. Once people were forced to liquidate their long-term assets, they become embroiled in recurrent cycles of hunger.

\section{COLONIAL INTERVENTIONS AND THE}

\section{ENTRENCHMENT OF THE HUNGRY SEASON GAP}

As one of the few places on the continent with data on precolonial food security, Banda provides us with a unique opportunity to interrogate the impact of colonial rule. From what we can tell, food security was significantly higher prior to European interventions. As discussed in chapter 2, Banda maintained a high level of food security during the drought of the fifteenth through seventeenth centuries, setting the bar much higher than the late nineteenth-century referent often used as a precolonial baseline. In the late eighteenth century and the first decades of the nineteenth century, although Asante demands redirected trade and siphoned at least some wealth from Banda, food privations seem to have been experienced only sporadically, during military engagements or upon capture. What is perhaps most telling in both of these cases is the minimal role played by maize, which suggests that its affordances, like the readiness of harvest before yams, were not central to meeting peoples' food security needs. Its relatively low usage suggests that such chronic shortages were not as commonplace as they became in the early colonial period. This argument has major implications for understanding why maize was adopted at variable rates across the continent. Rather than assuming that Africans were in need of maize's caloric and agronomic affordances, I have demonstrated that those needs were already met by indigenous grains, and that choice rather than privation defined precolonial Africans' choice of what to eat and grow. For most of the centuries in which it has been available, maize has been a solution in search of a problem.

In this chapter, I argue that the central problem-the hungry season gapseems to have become more severe and entrenched in the early colonial period. The early colonial period was certainly not the first time that people experienced hunger in Banda, Ghana, or wider West Africa. Both Shaffer (2017) and La Fleur (2012, 137-44) trace occurrences of famine in precolonial historical records, usually as a result of a severe environmental shock or war and violence, the latter relayed in oral histories in Banda as well. As Iliffe (1987) argues, famines seem to have been far more common throughout the premodern world-not just in 
Africa-prior to the development of steam and motorized transport, which allow states to move large quantities of food to areas most in need. But what about the seasonal, chronic hunger described in this chapter, which continues to affect far more people far more often than these severe events? Unfortunately the visibility of the hungry season in the records is much lower than that of severe events like famine, precisely because people have long managed to cope with predictable, chronic shortfalls in food supply and their effects are less noticeable than those of major food shortages. This relative invisibility led Watts (2013) to refer to seasonal, chronic hunger as "silent violence." If seasonal hunger flew beneath the colonial radar, we can also imagine that earlier chroniclers might not have recognized the signs, which might explain its absence in part in early documentary sources.

But it is possible to trace the hungry season in precolonial times and more work needs to be done to evaluate its severity and geographic spread. Oral historical and ethnographic accounts provide one major archive, and much more work could be done using historical linguistics to trace concepts of hunger back in time. Price records also suggest highs and lows in demand for food crops and reflect shortages; more might be done with earlier records from ship captains along the coast. As I've argued above, tracing the prevalence of maize and perhaps cassava provides another possibility, particularly in areas where they are known but not adopted with gusto. In these cases, it is critical that we also trace the specific historical contexts of maize adoption. Where its proliferation coincides with other warning signs, such as economic and demographic slumps, as in Banda, a stronger argument might be made for the existence of seasonal hunger.

The Banda case argues for a late emergence of chronic, seasonal hunger, which seems to become more pronounced in the early colonial period. But does this mean colonial policies are to blame for chronic hunger? And if so, how? This is a difficult problem to unravel because the dynamics at play are complex. The limitation of archive in this case means that sources that derive from the early colonial period are often used to argue for an earlier presence of the hunger season, as in Shaffer's (2017) argument. This issue is exacerbated by the structural functionalist leanings of the anthropologists who provided some of the most detailed and earliest records of rural agriculturalists like the Tallensi and the Bemba. Moore and Vaughan (1994) argue that Audrey Richards collapsed all changes prior to her arrival among the Bemba in the 1930s, even though the region's agricultural base had long been impacted by and responded to shifts in British policy. Fortes and Fortes adopt a similar perspective in some of their writings on the Tallensi, despite the fact that that group had been under British authority for forty years by the time they were made anthropological subjects. And British rule was hardly the first political change of guard that impacted foodways, as this book demonstrates. The dynamics that underlay the extension of formal colonial rule have their roots far earlier in time, and also took place in a volatile landscape that was anything but representative of the precolonial past. 
To understand the impact of colonial rule on African rural economies, most scholars have attempted to evaluate whether there is a direct link between specific colonial policies and African agricultural production or food security. This tactic would ideally allow for a clear cause-and-effect argument. Fortes and Shaffer, for example, evaluate the role of labor migration to the south, and conclude it is not of sufficient scale to explain Tallensi hunger. Unfortunately, this rather strict test of colonial impact discounts how multiple types of colonially imposed strategies interacted on the ground, a situation in which the colonial government's laissez faire attitude let changes run amok. Colonial economic and policy shifts did not happen in a vacuum, but against a backdrop of complex histories and local politics. While disentangling cause and effect becomes murkier in these situations, it is important to take this broader view, since colonial interventions likely had indirect effects on far greater numbers of people.

Consider, for example, Shaffer's $(2017,285)$ contention that changes in the social safety net or moral economy were factors "unrelated" to colonial polices, therefore outside of his attempt to evaluate colonialism's impact on food security. He is correct in that there was no official colonial policy that forbade people from sharing food with one another. Yet historian Elias Mandala and geographer Michael Watts have illustrated the strong impact of colonial economic policies on these social safety nets in Malawi and Nigeria, respectively. The emphasis on cash crop production meant that people devoted some resources formerly reserved for food production to new and often nonessential crops. This dynamic was especially alarming to colonial officers like Ormsby-Gore, who were concerned with African nutrition. While cash cropping was less important in Banda and Taleland than in cocoa-growing areas, both areas did rely on the cultivation and sale of smaller-scale cash crops like peanuts (Fortes and Fortes 1936). These seemingly subtle differences had a variety of implications for food security.

In Banda's case, there are multiple possible explanations for why food insecurity, and particularly the hunger season, became more pronounced in the late nineteenth and early twentieth centuries. While I make the case that some of these arguments better account for the available data, I should emphasize that all of these dynamics were probably at play at various points during the early colonial period. One possibility concerns a decline in the availability of farm labor. Colonial demands for labor, as well as labor migration, occurred in a context of very low population density. Yet it seems probable that Banda farmers adopted cassava to mitigate these challenges, and in this way may have staved off the worst shortages. Low labor availability also does not account for the increased presence of maize, which requires about the same amount of labor as does sorghum, though less than pearl millet.

While a paucity of labor was likely a contributing factor to Banda's food situation, market integration poses a much more serious problem. In Banda we have multiple material indicators of market activity, including British goods like pipes, 
pomades, and coinage. Banda residents must have traded something to acquire these goods. Archival sources point to Banda women selling food at Kintampo's market. We also have the recorded complaints lodged that Banda was not able to supply the required quantity of food produce to the colonial government at Kintampo. The selling of food crops to access cash is a significant economic shift with direct implications for food security. Even if Banda farmers were able to produce the same quantities of food that they had in the past (unlikely, given labor concerns), selling some at market reduced the amount available for consumption. The immediate consequence is that food supplies that would have normally gotten their families through the year likely ran short before the next year's harvest was ready. When food supplies ran short, the market was an option for people, but as colonial records indicate, prices of food were often double the norm during periods of high demand, particularly the hungry season. Banda's residents were mostly subsistence farmers and small-scale traders, so the lack of a lucrative cash crop like cocoa meant low profit margins overall. No wonder maize was adopted as a stopgap crop to bridge the resulting hungry season gap.

This particular configuration of market economies seems to have been a colonial introduction, especially for the vast interior regions of the Gold Coast. British officials had a vested interest in integrating northerners into the markets, and the selling of subsistence crops was seen as critical to this and was strongly encouraged. As described by Tudhope in 1912, the ideal African subject was one who consumed manufactured goods and supported this consumption habit through selling produce at market, even if the profit margin was small (see also Guyer 2004). Africans have long been involved in market economies to various degrees, most especially at marketplaces, which have existed since precolonial times (Stahl 2018a). But there is less evidence for the existence of a free market-where prices were determined by competition and supply/demand. Multiple scholars have argued, in fact, that precolonial African trade operated according to a different set of principles, and its products were valued and accumulated very differently than in a supply/demand economy (Guyer 2004).

Market integration likely had profound social impacts that directly impacted food access. Watts (2013) argues that in Nigeria, the replacement of moral economies with capitalist ones focused on the individual was perhaps the most significant disruption of the colonial era. "Moral economy", a term popularized by James Scott (1977), refers to a precapitalist form that involved community mechanisms such as sharing and redistribution to ensure household reproduction for the majority. In other words, there was a community ethic that everybody had a moral right to access food. Social and political structures were therefore bound up in this "subsistence ethic," which provided welfare and insurance against food shortfalls in times of need (Scott 1977, 40). These social structures acted to minimize risk, particularly environmental variation, over the long term. We may juxtapose this with a market or capitalist economy that commoditizes labor as well as foodstuffs 
and other agricultural products. With this transition, the emphasis for smallholder farmers shifted from insuring community well-being to accumulating wealth as an individual or household unit.

Watts's well-known study emphasized the role of cash crop production in this transition process. As part of incorporation into the market economy, and under the direct influence of colonial governments, many people opted for or were coerced into cash crop production. Income generated by cash crops was then used to purchase the foodstuffs needed for household survival. This shift in focus, however, subjected small-scale farmers to the "horrors and moodiness of markets without the benefits of transformed forces of production. The tissues of the moral economy were stripped away, making peasants vulnerable to both market forces and a capricious climate" (Watts 2013 [1983], xxiii). Fewer scholars have focused on the selling of subsistence crops, a common strategy for farmers like those in Banda who could not produce lucrative cash crops. Not only was the profit margin smaller on these crops, but selling them at market directly removed these foodstuffs from the family larder. Food supplies ran out sooner than they might have previously, entrenching chronic seasonal hunger and vulnerability into the Banda region almost instantaneously.

The shift from moral to market economies meant that food was no longer a right but a commodity subject to supply/demand pricing. Throughout history, various leveling mechanisms have redistributed food to people in need, though imperfectly and unequally. Indeed, Thompson's (1971) original moral economy model was based on the history of how food prices responded to the removal of protective regulations and the emergence of a free market in Britain in the late eighteenth century. The free market for food was seen as a "natural" means to move food from areas with surplus to areas in need. Famines, of course, were possible for those with less ability to access cash, but in this age of Malthus this was seen as a "natural" check on burgeoning populations. Food prices soon were off the charts and led to widespread food riots. This transition - to food as a commodity on the free market-was catastrophic for many of the poor in Britain. Precolonial data are insufficient in Ghana to address when and how food became subject to supply/ demand pricing, but it is likely that this change was associated with colonial economic policies as has been argued elsewhere (Mandala 2005; Watts 2013). Multiple sources suggest that this dynamic was at play in Taleland as well as near Banda in both the early and late colonial eras. Food prices at Kintampo, cited above, were double during the hungry season, as they were in Taleland (table 1). The need to purchase food through cash, especially during the height of the hungry season, would have spelled privation for a large number of poor people in the Gold Coast, much as it did in eighteenth century Britain. It is a shame that historical amnesia prevented British colonial officials from recalling this lesson.

In reality, the shift from moral to market economies is uneven, messy, and difficult to trace. "Moral economies," for example, did not lie completely outside 
the market in precolonial times. During the Atlantic trade, people responded to demands for craft production and trade on the Ghanaian coast by shifting their settlements to better maximize both (Kea 1982; DeCorse 2005). As Jane Guyer (2004) has demonstrated, the production of goods in order to access currencies has occurred for many centuries. African currencies have included cowrie shells, iron objects, and gold dust, among other things, traditions that extend back a millennium or more in some regions. In Banda, iron and copper currencies may have existed as early as the Ngre phase, and the presence of figurative "gold" weights as well as cowrie shells in the Kuulo phase suggests that such currencies were firmly embedded by that time. In other words, ideas of material wealth clearly existed alongside wealth in knowledge and people (Guyer 1995; Guyer and Belinga 1995). Maintenance of a moral economy may have helped accumulate wealth-in-people; assurances of welfare during times of need helped to ensure community wellbeing and underwrote the diverse assemblages of people and skills in a given community. Ideally, entitlements (land, cash, other tradeable goods) or access to food were thus ensured by community membership. However it would be a mistake to assume that "moral economies" (or Golden Ages) assured everyone equal or even adequate access to food.

Toby Green (2019) has argued that inequality became more pronounced in many West African societies in the centuries and decades preceding formal colonial rule, complicating a neat narrative of a shift from a moral to market economies. Through global trade connections in gold and human captives, some people and groups were able to acquire and accumulate wealth. This argument implies that the landscape inherited by colonial rulers was a profoundly unequal one, with major implications for food security. Add supply/demand food pricing to these socioeconomic disparities, and the ingredients for persistent, chronic hunger among a poor underclass are clearly present. Colonial price records already show that food crops were double the price during the hungry season, speaking both to the high demand for these crops and their relative inaccessibility for people without entitlements. In Banda, we have little evidence for pronounced inequality among residents, but recall that integration into the Asante state laid the foundations for inequality on a larger scale by siphoning surpluses into state coffers. Reading Banda's record against this broader regional landscape of inequality illustrates the need to drill down into more specific local case studies in order to unravel the political dynamics at the heart of food access across space and time.

Many local societies retained or developed important social-leveling mechanisms that fought back against some of the problems associated with market economies. Some elements of precolonial moral economies, like food sharing, persist in places like Banda to this day in some forms even though they have been abandoned elsewhere (Cliggett 2005; Holtzmann 2009; Mandala 2005). By the time of Fortes and Fortes's visit, this process seems to have been well underway in Taleland. Fortes and Fortes (1936) detail how members of Tallensi extended 
households pooled labor, especially for agriculture. Working for the head of household may have been a way to access food in the early growing season, since labor is often repaid in food (Watts 2013, 127). But food was not shared among members of a household; most economic interactions were also independent. When food was needed, women would visit their extended relations in other villages or households. In fact, there do not appear to have been any nonkin redistribution systems to help the poor, as would be expected in a moral economy; instead, the chief was the richest man in town, and kept this wealth to himself and his family. Was this a pattern born of integration into market economies? The lack of precolonial data prevents us from evaluating this proposition.

In closing, it is important to highlight how the colonial government's presumption of what caused hunger limited its ability to address the problem, as this has implications for how we approach hunger in the continent today. Although nutrition in the interior regions was largely ignored, colonial officials did attempt to improve health through enforcing "sanitation" policies." These policies were perhaps more consistent with colonial views of Africans as dirty and backward, and of themselves as civilizers. Changing nutritional outcomes would have meant recognizing malnutrition as a problem in the first place. This had potential to be a great embarrassment for the British colonial enterprise, particularly since nutrition went hand-in-hand with agricultural production, something that could not wholly be blamed on perceived African shortcomings. When nutritional problems were noted, such as Purcell's (1939) catalog of deficiency diseases on the coast, or Fortes and Fortes's (1936) description of the hungry season gap among the Tallensi, these were almost always blamed on African people and environments. While I agree with Shaffer (2017) that claims about the impact of colonial policies on nutrition need to be carefully evaluated on a case-by-case basis rather than generalizing about colonialism as a whole, it seems telling that the reverse explanations-that hunger has always existed-are rarely evaluated with the same caution. This "light touch" evaluation of colonialism also sidesteps clear evidence for the "malign neglect of officials" (Robins 2018, 168) towards scientifically documented severe malnutrition. Negligence may have been as destructive, if not more so, than targeted interventions, yet the major economic and social changes induced by colonial governments are let off the hook, because their effects were not deliberate. 